
ВИВЧЕННЯ ТЕМИ «ВІДДІЛЕННЯ ЛІКАРНІ» НА ЗАНЯТТЯХ З УКРАЇНСЬКОЇ
МОВИ ЯК ІНОЗЕМНОЇ У ЗАКЛАДАХ ВИЩОЇ МЕДИЧНОЇ ОСВІТИ (СТАТТЯ 1)

\title{
STUDY OF THE THEME «HOSPITAL DEPARTMENTS» AT THE LESSONS IN UKRAINIAN AS A FOREIGN LANGUAGE IN ESTABLISHMENTS OF HIGHER MEDICAL EDUCATION (ARTICLE 1)
}

\begin{abstract}
у статті подано навчально-методичні матеріали до вивчення теми «Відділення лікарні» (перше заняття) на заняттях з української мови як іноземної у закладах вищої медичної освіти. Вивчення дисципліни «Українська мова як іноземна» у закладах вищої освіти є однією зі складових адаптаціі студентів у чужому соціокультурному просторі та передбачає практичне оволодіння мовою з метою вирішення комунікативних цілей у побутовій, соціокультурній, навчальній, науковій сорерах. Обірунтовано необхідність розробки методики вивчення медич них тем на заняттях з української мови як іноземної, яка б сприяла формуванню комунікативної компетениії студентів-медиків, забезпеченню базових комунікативних потреб у навчально-просресійній ссрері. Комплекс завдань розроблений з урахуванням програмних вимог, комунікативних і пізнавальних потреб іноземних студентів, ґрунтується на принципах науковості, систематичності та послідовності, доступності, зв'язку теорії з практикою і орієнтований на реалізацію комунікативного підходу. Вправи спрямовані на збагачення словникового запасу студентів, зокрема тренують уживання в мовленні номінацій на позначення відділень лікарні, систем організму, частин тіла людини, хвороб, травм ma їх симптомів; розширення знань про граматичні категорії, вдосконалення навичок уживання іменників та прикметників у родовому і знахідному відмінках, побудови словосполучень, речень; розвиток усного й писемного мовлення. Зміст заняття та окреслені види робіт дозволяють одночасно із засвоєнням лексико-граматичного матеріалу формувати фрахову комунікативну компетениію майбутніх медиків. Дидактичний матеріалапробованийнапрактичнихзаняттях з української мови як іноземної автором публікації. Запропонована методична розробка призначена для студентів, які володіють українською мовою на початковому рівні. Ключові слова: українська мова як іноземна, методична розробка, профресійне спілкування, навчально-методичні матеріали, комунікативна компетенція.
\end{abstract}

The article presents educational and methodological materials to the study of the theme «Hospital Departments» (the first lesson) at the lessons of Ukrainian as a foreign language in institutions of higher medical education. Studying the subject «Ukrainian as a Foreign Language» in higher educational establishments is one of the components of adaptation of students in a foreign sociocultural space and provides for practical mastery of the language in order to solve communicative goals in every day, sociocultural, educational and scientific fields. The necessity of developing a methodology for studying medical topics at classes in Ukrainian as a foreign language is substantiated. Knowledge and skill got during the classes contributes to the formation of communicative competence of medical students, and to the provision of basic communicative needs in the educational and professional field. The set of tasks is composed with regard to the program requirements, communicative and cognitive needs of foreign students, is based on the principles of scientific, systematic and consistent, accessibility, linking theory with practice and oriented towards the implementation of a communicative approach. Exercises are aimed at enriching the vocabulary of students, in particular, training the use in speaking of nominations for the denoting of departments of the hospital, body systems, parts of the human body, diseases, injuries and their symptoms; expanding knowledge of grammatical categories, improving the use of nouns and adjectives in Accusative Case and Genetive Case, constructing phrases, sentences; development of spoken and written language. The content of the class and the outlined types of work allow simultaneously with the mastering of lexical and grammatical material to form the professional communicative competence of future doctors. Didactic material was tested in the practical lessons in Ukrainian as a foreign language by author of the publication. The proposed methodological material is intended for students who speak Ukrainian at an elementary level.

Key words: Ukrainian as a foreign language, methodological instruction, professional communication, teaching materials, communicative competence. медичного університету

імені І.Я. Горбачевського
Постановка проблеми в загальному вигляді. Вивчення дисципліни «Українська мова як іноземна» в закладах вищої освіти є однією із складових адаптації студентів у чужому соціокультурному просторі та передбачає практичне оволодіння мовою 3 метою вирішення комунікативних цілей у побутовій, соціокультурній, навчальній, науковій сорерах. Оволодіння українською мовою сприяє професійному становленню майбутніх фрахівців, оскільки впливає на результативність спілкування в українськомовному професійному середовищі, уможливлює ведення фрахово зорієн- тованого компетентного спілкування. У цьому аспекті актуальним $€$ розробка навчальнометодичного забезпечення дисципліни з огляду на обрану спеціальність студентами-іноземцями.

Аналіз останніх досліджень і публікацій. Розширення сорер міжнародної та міжкультурної комунікації у сорері освіти сприяло зростанню інтересу до методики викладання української мови як іноземної. Проблема фрормування українськомовної компетенції $€$ предметом наукового зацікавлення багатьох учених, зокрема Н.С. Голод, Н.В. Кобзей, Н.Л. Куйловської та інших. [див. 1, 2, 3]. Розробка 
навчально-методичних матеріалів із курсу «Українська мова як іноземна» для підготовки фрахівців медичних спеціальностей представлена в підручниках і посібниках [див. 4, 5, 6, 7, 8].

Виділення не вирішених раніше частин загальної проблеми. В українській лінгводидактиці фрормування комунікативної компетенції іноземних студентів у сорері профресійного спілкування фрахівців медичних спеціальностей недостатньо розроблене, що вмотивовує актуальність праці.

Мета статті - запропонувати методичну розробку для викладача до теми «Відділення лікарні». Дидактичний матеріал апробований на практичних заняттях з української мови як іноземної автором публікації та зорієнтований на фрормування вмінь і навичок професійної комунікації.

Виклад основного матеріалу. Темі «Відділення лікарні» присвячено два практичні заняття. У публікації пропонуємо навчально-методичні матеріали до першого заняття. Запропоновані завдання передбачають: розширення фрахового словникового запасу, зокрема вивчення слів і словосполучень на позначення відділень лікарні, систем організму, частин тіла людини, хвороб, травм та їх симптомів; розвиток навичок роботи 3 текстом; практикування вживання іменників і прикметників у родовому та знахідному відмінках; розвиток усного і писемного мовлення.

\section{Завдання 1. Запам'ятайте.}

\begin{tabular}{|l|l|}
\hline \multicolumn{2}{|c|}{ Відділення лікарні } \\
\hline $\begin{array}{l}\text { відділення анестезіології } \\
\text { та інтенсивної терапії }\end{array}$ & $\begin{array}{l}\text { department of } \\
\text { anesthesiology and } \\
\text { intensive care }\end{array}$ \\
\hline $\begin{array}{l}\text { гастроентерологічне } \\
\text { відділення }\end{array}$ & $\begin{array}{l}\text { gastroenterological } \\
\text { department }\end{array}$ \\
\hline $\begin{array}{l}\text { ендокринологічне } \\
\text { відділення }\end{array}$ & ndocrinology department \\
\hline кардіологічне відділення & cardiology department \\
\hline $\begin{array}{l}\text { ортопедо-травматологічне } \\
\text { відділення }\end{array}$ & $\begin{array}{l}\text { orthopedic and } \\
\text { traumatological department }\end{array}$ \\
\hline $\begin{array}{l}\text { оториноларингологічне } \\
\text { відділення }\end{array}$ & $\begin{array}{l}\text { otorhinolaryngology } \\
\text { department }\end{array}$ \\
\hline $\begin{array}{l}\text { остальмологічне } \\
\text { відділення }\end{array}$ & ophthalmologic department \\
\hline $\begin{array}{l}\text { пульмонологічне } \\
\text { відділення }\end{array}$ & department of pulmonology \\
\hline урологічне відділення & urological department \\
\hline хірургічне відділення & department of surgery \\
\hline
\end{tabular}

Завдання 2. Поєднайте слова з колонок А і Б.

\begin{tabular}{|l|l|}
\hline \multicolumn{1}{|c|}{ С } & \multicolumn{1}{|c|}{ Система організму }
\end{tabular}

\begin{tabular}{|l|l|}
\hline 4. Органи дихання & Г. Очі \\
\hline 5. Органи зору & Ґ. Вухо, горло, ніс \\
\hline 6. Органи травлення & $\begin{array}{l}\text { Д. Бронхи, легені, плевра, } \\
\text { трахея }\end{array}$ \\
\hline $\begin{array}{l}\text { 7. Серцево-судинна } \\
\text { система }\end{array}$ & $\begin{array}{l}\text { Е. Дванадцятипала } \\
\text { кишка, жовчний міхур, } \\
\text { печінка, підшлункова } \\
\text { залоза, шлунок }\end{array}$ \\
\hline 8. Сечовидільна система & Є. Щитоподібна залоза \\
\hline
\end{tabular}

Завдання 3. Читайте текст.

\section{Відділення лікарні}

У лікарні $є$ різні відділення. Тут пацієнти отримують спеціалізовану медичну допомогу.

У хірургічному відділенні оперують хворих. Хірурги проводять різні операції, наприклад, видаляють апендикс при апендициті, ампутують кінцівки, трансплантують органи. Хірургічні операції проводять в операційній кімнаті. Лікарі-хірурги використовують хірургічні інструменти: скальпель, ножиці, операційний ніж. Лікарі-анестезіологи працюють у відділенні анестезіології та інтенсивної терапії. Вони забезпечують анестезію під час проведення операцій. $€$ загальна та місцева анестезія.

В урологічному відділенні лікують захворювання сечовидільної системи: цистит, сечокам'яну хворобу, патологію сечового міхура.

В ортопедо-травматологічному відділенні лікують травми та захворювання опорно-рухового апарату, наприклад, вивих, перелом.

В оториноларингологічному відділенні лікують різні захворювання ЛОР-органів: аденоїдит, отит, синусит, тонзиліт.

В офтальмологічному відділенні лікують захворювання органів зору, наприклад, короткозорість, далекозорість, астигматизм, катаракту.

У кардіологічному відділенні лікують захворювання серцево-судинної системи: ішемічну хворобу серця, гіпертонічну хворобу, міокардит, аритмію і розлади кровообігу.

У гастроентерологічному відділенні лікують захворювання органів травлення, наприклад, гастрит, виразку, гепатит C, панкреатит, холецистит.

В ендокринологічному відділенні лікують захворювання ендокринної системи: цукровий діабет, патологію щитоподібної залози.

У пульмонологічному відділенні лікують хвороби органів дихання: бронхіальну астму, пневмонію, алергічні захворювання.

\section{Завдання 4. Відповідайте.}

1. Які хірургічні операції проводять хірурги? 2. Які спеціальні інструменти використовує хірург? 3. Які є види анестезії? 4. Які є захворювання сечовидільної системи? 5. Які є хвороби органів зору? 6. Які $€$ захворювання серцевосудинної системи? 7. Які є органи травлення? 
8. Які $€$ захворювання органів травлення? 9. Які $€$ захворювання ендокринної системи? 10. Які є органи дихання? 11. Які є захворювання органів дихання? 12. Які частини тіла належать до опорно-рухового апарату? 13. Які $€$ травми опорно-рухового апарату? 14. Які $€$ захворювання ЛОР-органів?

Завдання 5. Читайте. Запам'ятайте.

\begin{tabular}{|c|c|}
\hline що? & $\begin{array}{c}\text { Захворювання, травма, } \\
\text { патологія } \\
\text { Чого? }\end{array}$ \\
\hline Називний відмінок & Родовий відмінок \\
\hline \multicolumn{2}{|c|}{ Чоловічий рід } \\
\hline хребет & хребта \\
\hline шлунок & шлунка \\
\hline & Hoca \\
\hline жовчний міхур & жовчного міхура \\
\hline опорно-руховий апарат & опорно-рухового апарату \\
\hline \multicolumn{2}{|c|}{ Жіночий рід } \\
\hline печінка & печінки \\
\hline плевра & плеври \\
\hline ключиця & ключиці \\
\hline трахея & трахеї \\
\hline підшлункова залоза & підшлункової залози \\
\hline серцево-судинна система & $\begin{array}{l}\text { серцево-судинної сис- } \\
\text { теми }\end{array}$ \\
\hline \multicolumn{2}{|c|}{ Середній рід } \\
\hline $\begin{array}{l}\text { вухо } \\
\text { плече } \\
\text { праве копіно }\end{array}$ & $\begin{array}{l}\text { вуха } \\
\text { плеча } \\
\text { правого копіна }\end{array}$ \\
\hline \multicolumn{2}{|c|}{ Множина } \\
\hline $\begin{array}{l}\text { очі } \\
\text { бронхи } \\
\text { органи дихання }\end{array}$ & $\begin{array}{l}\text { очей } \\
\text { бронхів } \\
\text { органів дихання }\end{array}$ \\
\hline $\begin{array}{l}\text { У хворого що? } \\
\text { Болить що? }\end{array}$ & $\begin{array}{l}\text { Хворий на що? Лікувати } \\
\text { що? } \\
\text { Травмувати що? Зламати } \\
\text { що? }\end{array}$ \\
\hline Називний відмінок & Знахідний відмінок \\
\hline \multicolumn{2}{|c|}{ Чоловічий рід } \\
\hline Hic & HiC \\
\hline синусит & синусит \\
\hline отит & отит \\
\hline цукровий діабет & цукровий діабет \\
\hline \multicolumn{2}{|c|}{ Жіночий рід } \\
\hline ключиця & ключицю \\
\hline катаракта & катаракту \\
\hline пневмонія & пневмонію \\
\hline бронхіальна астма & бронхіальну астму \\
\hline $\begin{array}{l}\text { гіпертонічна хвороба } \\
\text { ішемічна хвороба серця }\end{array}$ & $\begin{array}{l}\text { гіпертонічну хворобу } \\
\text { ішемічну хворобу серця }\end{array}$ \\
\hline патологія щитоподібної & патологію щитоподібної \\
\hline залози & залози \\
\hline далекозорість & далекозорість \\
\hline короткозорість & короткозорість \\
\hline \multicolumn{2}{|c|}{ Середній рід } \\
\hline $\begin{array}{l}\text { захворювання } \\
\text { вухо }\end{array}$ & $\begin{array}{l}\text { захворювання } \\
\text { вухо }\end{array}$ \\
\hline \multicolumn{2}{|c|}{ Множина } \\
\hline $\begin{array}{l}\text { розлади кровообігу } \\
\text { пальці }\end{array}$ & $\begin{array}{l}\text { розлади кровообігу } \\
\text { пальці }\end{array}$ \\
\hline
\end{tabular}

Завдання 6. Пишіть речення.

1. Ішемічна хвороба серця $€$ поширеним захворюванням (серцево-судинна система). 2. У пульмонологічному відділенні лікують (бронхіальна астма, пневмонія). 3. Хворі на (цукровий діабет) повинні постійно перевіряти рівень цукру у крові. 4. Антон бере інгалятор, коли бігає, бо він хворий на (астма). 5. Гастроентеролог радив хворому на (виразка) дотримуватися дієти. 6. Виразка - це захворювання (шлунок). 7. Під час аварії водій травмував (стегно), а пасажир (ключиця). 8. Отоларинголог лікує захворювання (ЛОР-органи), наприклад, (отит, синусит, аденоїдит). 9. Під час гри у фрутбол мій друг отримав травму (ліве коліно). 10. Хлопець упав і зламав (нога). 11. Хворий із травмою (хребет) не може самостійно ходити. 12. В офтальмологічному відділенні лікують захворювання (очі). 13. Гастрит, виразка, гепатит C, панкреатит - це хвороби (органи травлення). 14. Чоловік страждає від рідкісного захворювання (печінка).

Завдання 7. Поєднайте колонки А і Б. Запишіть словосполучення.

\begin{tabular}{|c|c|}
\hline A & Б \\
\hline бронхіальна & ніж \\
\hline операційна & хвороба \\
\hline підшлункова & залоза \\
\hline трансплантація & діабет \\
\hline операційний & кровообіг \\
\hline розлад & апендикс \\
\hline сечовий & астма \\
\hline отоларингологічне & система \\
\hline видалення & кімната \\
\hline цукровий & нирка \\
\hline перелом & анестезія \\
\hline сечовидільна & відділення \\
\hline місцева & стегно \\
\hline сечокам'яна & міхур \\
\hline
\end{tabular}

Завдання 8. Доповніть речення. Використовуйте словосполучення із завдання 7.

1. У пульмонологічному відділенні лікують захворювання органів дихання, наприклад, ... 2. Лікар-хірург використовує спеціальний хірургічний інструмент - ... 3. Хірургічні операції проводять в ... 4. ... - це захворювання ендокринної системи, яке лікують в ендокринологічному відділенні. 5. ... - це операція, яку проводять при апендициті. 6. Патологію ... лікують в урологічному відділенні. 7. В ортопедо-травматологічному відділенні лікують травми опорно-рухового апарату, наприклад, ... 8. В урологічному відділенні лікують хвороби ... 9. До органів травлення належать шлунок, печінка, жовчний міхур, ... 10. Кардіолог - це спеціаліст, який лікує хвороби серцево-судинної системи: міокардит, аритмію, ... 11. Хворому потрібна термінова ... 12. В ... лікують хворих на аденоїдит, отит, 
синусит. 13. При хірургічних операціях застосовують загальну або ... 14. Уролог лікує захворювання органів сечовидільної системи, наприклад, ...

\section{Завдання 9. Правильно чи неправильно?}

1. В урологічному відділенні лікують захворювання органів сечостатевої системи: легень, трахеї, бронхів, плеври. 2. До органів травлення належать шлунок, підшлункова залоза, печінка, жовчний міхур, дванадцятипала кишка. 3. Короткозорість, далекозорість, астигматизм, катаракта - це захворювання опорно-рухового апарату. 4. В офтальмологічному відділенні лікують захворювання органів зору. 5. В ендокринологічному відділенні лікують хворих на цукровий діабет. 6. Травми хребта, суглобів, ключиці, перелом кінцівки лікують у пульмонологічному відділенні. 7. Бронхіальна астма, пневмонія - це хвороби органів сечовидільної системи. 8. До органів дихання належать серце, артерії, капіляри, вени. 9. Хворих на катаракту лікують в отоларингологічному відділенні. 10. Гастрит, виразка, гепатит C, панкреатит, холецистит - це хвороби органів дихання. 11. Лікарі-ендокринологи видаляють апендикс при апендициті, ампутують кінцівки, трансплантують органи. 12. Пульмонолог - це спеціаліст, який лікує захворювання органів дихання. 13. У кардіологічному відділенні лікують гіпертонічну хворобу, міокардит, аритмію і розлади кровообігу. 14. До серцево-судинної системи належать нирки, сечовий міхур.

Висновки. Вивчення іноземними студентами мови країни, у якій вони навчаються, відіграє важливу роль у професійному становленні, оскільки забезпечує еорективне фахове спілкування у професійному середовищі, адже володіння лише англійською мовою не забезпечує усіх комунікативних потреб. Запропонований нами дидактичний матеріал розроблений 3 урахуванням комунікативних і пізнавальних потреб іноземних студентів-медиків та сприяє розширенню лексичної бази, розвитку умінь будувати власне висловлювання, вдосконаленню навичок уживання іменників та прикметників у родовому і знахідному відмінках, ґрунтується на принципах науковості, систематичності та послідовності, доступності, зв'язку теорії з практикою і спрямований на реалізацію комунікативного підходу.

Перспективу подальших пошуків вбачаємо в розробленні навчально-методичних матеріалів до занять медичної тематики.

\section{БІБЛІОГРАФІЧНИЙ СПИСОК:}

1. Голод Н.С., Панчишин М.В., Родчин 3.Я. Українська мова як іноземна: навчально-методичне видання. Івано-Франківськ, 2014. Ч. 1. 202 с.

2. Кобзей Н.В., Соловій У.В. Українська мова як іноземна: навчально-методичне видання. ІваноФранківськ, 2014. Ч. 1. 138 с.

3. Куйловська Н.Л., Соловій У.В. Українська мова як іноземна: навчально-методичне видання. Івано-Франківськ, 2015. Ч.1. 148 с.

4. Лещенко Т.О., Шарбенко Т.В., Юфименко В.Г. Українська мова в медицині : навч. посіб. для самостійної роботи студентів вищих навчальних закладів МО3 України. Полтава, 2017. 332 с.

5. Силка А. А. Українська мова для студентівіноземців медичного профрілю (з англійською мовою навчання) : навч. посіб. Суми, 2019. 130 с.

6. Українська мова як іноземна для англомовних студентів-медиків: підручник з електрон. аудіодод. : у 2 кн. Кн. 1. Соціокультурна комунікація / С.М. Луцак, А.В. Ільків, Н.П. Литвиненко та ін. ; за ред. С.М. Луцак. Київ: ВСВ «Медицина», 2019. 504 с.

7. Українська мова як іноземна для англомовних студентів-медиків: підруч. 3 електрон. аудіодод. : у 2 кн. Кн. 2. Основи профресійного мовлення / С.М. Луцак, А.В. Ільків, О.І. Криницька та ін. ; за ред. С.М. Луцак. К.: ВСВ «Медицина», 2019. 456 с.

8. Українська мова як іноземна для студентів медичних спеціальностей: навчальний посібник / Гаврищак І.І., Драч І.Д., Заліпська І.Я. та ін. ; за ред. М.П. Тишковець. Тернопіль: ТНМУ, 2019. 312 с. 